\title{
The gastro-esophageal reflux disease questionnaire using Indonesian language: a language validation survey
}

\author{
Marcellus Simadibrata, ${ }^{1}$ Aziz Rani, ${ }^{1}$ Pangestu Adi, ${ }^{2}$ Ali Djumhana, ${ }^{3}$ Murdani Abdullah ${ }^{1}$ \\ ${ }^{1}$ Division Gastroenterology Department of Internal Medicine Faculty of Medicine University of Indonesia/Dr.Cipto \\ Mangunkusumo Hospital Jakarta, Indonesia \\ ${ }^{2}$ Division Gastroenterology Department of Internal Medicine Faculty of Medicine University of Airlangga/Dr. Soetomo \\ Hospital Surabaya, Indonesia \\ ${ }^{3}$ Division Gastroenterology Department of Internal Medicine Faculty of Medicine University of Padjadjaran/Dr.Hasan \\ Sadikin Hospital Bandung, Indonesia
}

\begin{abstract}
Abstrak
Latar belakang: Untuk menilai kegunaan dari kuesioner Gastro-esophageal Reflux Disease (GERD) pada diagnosis GERD, untuk memvalidasi kuesioner GERD yang ditulis dalam bahasa Indonesia, dan untuk mengevaluasi reabilitas dari kuesioner GERD yang ditujukan untuk pasien GERD yang berbahasa Indonesia (Studi Virginia).

Metode: Studi ini menggunakan survei yang bersifat prospektif pada 40 pasien yang terdiagnosis GERD berdasarkan pemeriksaan endoskopi di 3 kota besar di Indonesia (Jakarta, Bandung, dan Surabaya) dari 15 Januari sampai dengan 15 Mei 2009. Pasien diminta untuk melengkapi kuesioner GERD dan dinilai validitas dan reliabilitas dari kuesioner tersebut.

Hasil: Persentase responden yang melaporkan gejala selama 4-7 hari adalah sebagai berikut: $67.5 \%$ mengalami rasa seperti terbakar di bagian belakang tulang dada (heartburn); 65.0\% merasa isi lambung (cairan atau makanan) naik ke arah kerongkongan atau mulut (regurgitasi); $70 \%$ merasa nyeri pada bagian tengah perut atas; $57.5 \%$ mengalami rasa mual; 62.5\% mengalami kesulitan tidur yang dikarenakan heartburn dan / atau regurgitasi; dan 62.5\% meminum obat tambahan untuk heartburn dan / atau regurgitasi selain dari apa yang telah dianjurkan woleh dokter. Nilai alpha Cronbach adalah 0.834, yang menunjukkan bahwa seluruh pertanyaan dalam kuesioner GERD yang berbahasa Indonesia adalah valid dan reliabel untuk pasien GERD Indonesia.

Kesimpulan: Studi ini mencapai tujuan utamanya dan menunjukkan bahwa kuesioner GERD memiliki validitas dan reliabilitas yang baik untuk digunakan pada pasien GERD yang berbahasa Indonesia. Hasil penelitian ini sejalan dengan penelitian DIAMOND, yang menunjukkan bahwa kuesioner GERD dapat digunakan untuk mendiagnosis GERD pada gejala awal yang dilaporkan. (Med J Indones 2011; 20:125-30)
\end{abstract}

\begin{abstract}
Background: The aims of this study were to test the usefulness of the Gastro-esophageal Reflux Disease Questionnaire (GERDQ) in the diagnosis of GERD, to validate the GERDQ written in Indonesian language, and to evaluate the reliability of the GERDQ for use in Indonesian-speaking GERD patients (Virginia study).

Methods: This was a prospective survey of 40 patients diagnosed with GERD, based on an endoscopic examination, in 3 cities in Indonesia (Jakarta, Bandung, and Surabaya) from 15 January to 15 May 2009. Patients were asked to complete the GERDQ, and the validity and reliability of the questionnaire were assessed.

Results: The percentages of respondents who reported symptoms lasting 4-7 days were as follows: 68\% had a burning sensation behind the breastbone (heartburn); $65 \%$ had stomach content (fluid) move upwards to the throat or mouth (regurgitation); $70 \%$ had a pain in the centre of the upper abdomen; 58\% had nausea; $63 \%$ had difficulty sleeping because of the heartburn and/or regurgitation; and 63\% took additional medication for heartburn and/or regurgitation. Cronbach's alpha was 0.83, indicating that all of the questions in the Indonesian-language GERDQ are valid and reliable for Indonesian GERD patients.

Conclusions: This study achieved the primary objectives and showed that the GERDQ is valid and reliable for use with Indonesian-speaking GERD patients. The results were consistent with those of the DIAMOND study, which showed that the GERDQ can be used to diagnose GERD on the basis of the reported symptoms. (Med J Indones 2011; 20:125-30)
\end{abstract}

Key word: GERD, GERDQ, Reliability test, Validity test, Virginia study

Gastro-oesophageal reflux disease (GERD) is a condition that develops when reflux of the stomach's contents causes troublesome symptoms or complications. ${ }^{1}$ GERD is a chronic disease and causes persistent symptoms in $79-87 \%$ of patients. Although the disease itself is benign and the prevalence of complications and severe GERDrelated morbidity is low, GERD can severely reduce a patient's quality of life. ${ }^{2,3}$

Correspondence email to: gastroenterologi.rscm@gmail.com
GERD is common but its prevalence varies between different parts of the world. GERD is highly prevalent in Western countries, ${ }^{1,3}$ affecting $10-30 \%$ of the population. In Singapore, the prevalence of GERD symptoms increased from $1.6 \%$ of the population in 1994 to $10.6 \%$ in 2001. ${ }^{1,4-6}$ The prevalence of GERD in Hong Kong was $35 \%$ of the population in 2003. ${ }^{7}$ 
Endoscopy and oesophageal 24-h pH monitoring were initially proposed as the gold standards for the diagnosis of GERD ${ }^{8,9}$ However, it is estimated that up to $70 \%$ of patients with typical symptoms of GERD have normal oesophageal mucosa on upper endoscopy (non-erosive reflux disease) or endoscopy-negative reflux disease. ${ }^{9}$ Oesophageal 24-h ambulatory $\mathrm{pH}$ monitoring is not sensitive enough to serve as a diagnostic criterion. A Chinese GERD study group found that only 63 of 102 GERD patients were endoscopy positive and only 84 of 115 patients had a positive $\mathrm{pH}$ test result. ${ }^{9}$ Therefore, about $25 \%$ of patients cannot be diagnosed using this method. Furthermore, endoscopy and $\mathrm{pH}$ testing are expensive and are not available in small hospitals or clinics. Because there is no gold standard for diagnosing and evaluating GERD, the valid assessment of symptoms is especially important. ${ }^{8-11}$

Although a combination of symptom scoring and endoscopy has been shown to diagnose GERD with high specificity, it is increasingly accepted that management of GERD in primary care is best addressed on the basis of the patient's report of his or her symptoms. ${ }^{12}$

Several communication tools are used to help the physician make appropriate management decisions. In 2001, Shaw et al. ${ }^{2}$ developed a brief, simple 12-item questionnaire called the Reflux Disease Questionnaire (RDQ), which is reproducible and reliable for the diagnosis of GERD. Although the specificity is low (50\%), the RDQ has high sensitivity (94.12\%), good psychometric properties, is responsive to changes in health, and is well suited for use in both primary care settings and epidemiological studies.

Jones et al. developed and tested the GERD Impact Scale (GIS), a short questionnaire to aid patient-doctor communication. The GIS is a 1-page questionnaire that asks GERD patients about their symptoms and how these affect their everyday lives. It has been validated in a study involving 205 primary care patients with a new or existing diagnosis of GERD. The GIS demonstrated good psychometric properties in newly diagnosed GERD patients and those already receiving treatment. This simple communication tool is a useful aid for managing primary care patients with GERD. ${ }^{12}$

Indonesian people have many ethnics and languages, so it is very difficult to translate the GERD symptoms uniformly due to the expression variations.

Current GERD monitoring instruments are not appropriate because they do not assess daily symptoms, are not sufficiently responsive to short-term changes in health status, or have not been validated. To address these problems, the conceptual and psychometric requirements for a GERD symptom assessment questionnaire were identified used to create the GERD Questionnaire (GERDQ). ${ }^{3}$ The GERDQ was created from 3 different validated questionnaires evaluated in the DIAMOND study. ${ }^{13}$ The GERDQ is a simple communication tool developed for physicians to identify and manage patients with GERD. The aim of this survey was to test whether the GERDQ is effective in diagnosing GERD, to validate the GERDQ written in Bahasa Indonesia, and to evaluate its reliability when used with Indonesian-speaking GERD patients (Virginia study = validated Survey of GERDQ in Indonesia).

\section{METHODS}

This was a prospective survey in a multi-centre study of subjects who were evaluated and diagnosed as having GERD by endoscopic examination in 3 cities in Indonesia: Jakarta, Bandung, and Surabaya.

All patients with GERD symptoms who underwent an oesophago-gastro-duodenoscopy (EGD) examination in Dr. Cipto Mangunkusumo Hospital Jakarta, Dr. Soetomo Hospital Surabaya, and Dr. Hasan Sadikin Hospital Bandung, from 15 January to 15 May 2009 were included in this study. The sample comprised 40 patients who underwent EGD examination, showed a mucosal break or endoscopic oesophagitis associated with GERD, and fulfilled the inclusion criteria, which are 18 years old or more, and willing to give informed consent. The patients consuming proton pump inhibitor as $\mathrm{H}_{2}$ receptor antagonist and lunable to provide informed consent are excluded.

Aconsecutivesamplingmethod wasused.Afterthediagnosis by endoscopy, the investigator recorded the demographic data, performed a standard physical examination, and recorded the risk factors for GERD for each patient. The patient was then asked to complete the GERDQ.

The protocol has been reviewd and approved by the committec of the Medical Research Ethics of the Faculty of Medicine, University of Indonesia

Descriptive statistics are presented as the mean (SD), median (range), or number (\%). To test the internal consistency, Cronbach's alpha (a) was calculated to estimate how consistently the patients responded to the separate questions within each domain. a values of 0.70 or higher were considered sufficient.

The validity test was used to assess the accuracy construct of the questionnaire. The test was performed by comparing the $r$ value for each question based on the corrected item total correlation with the tabulated $\mathrm{r}$ value $(\mathrm{df}=38)$. Questions with $r$ value greater than the tabulated $r$ value were accepted as valid questions. The questions with $r$ value less than the tabulated $r$ value were deemed invalid and were deleted from the questionnaire. 
The GERD questionnaire in Indonesian language

\begin{tabular}{|c|c|c|c|c|c|c|}
\hline \multirow{2}{*}{ Pertanyaan } & & \multicolumn{5}{|c|}{ Frekuensi gejala yang dialami dalam 7 hari terakhir } \\
\hline & & 0 hari & 1 hari & 2-3 hari & 4-7 hari & \\
\hline $\begin{array}{l}\text { 1. Seberapa sering Anda mengalami rasa seperti terbakar di bagian belakang } \\
\text { tulang dada (heartburn)? }\end{array}$ & Poin & 0 & 1 & 2 & 3 & $\begin{array}{l}\text { Poin } \\
+\end{array}$ \\
\hline $\begin{array}{l}\text { 2. Seberapa sering Anda merasa isi lambung (cairan atau makanan) naik ke } \\
\text { arah kerongan atau mulut (regurgitasi)? }\end{array}$ & Poin & 0 & 1 & 2 & 3 & $\begin{array}{l}\text { Poin } \\
+\end{array}$ \\
\hline 3. Seberapa sering Anda merasa nyeri pada bagian tengah perut atas? & Poin & 3 & 2 & 1 & 0 & $\begin{array}{l}\text { Poin } \\
+\end{array}$ \\
\hline 4. Seberapa sering Anda merasa mual? & Poin & 3 & 2 & 1 & 0 & $\begin{array}{l}\text { Poin } \\
+\end{array}$ \\
\hline $\begin{array}{l}\text { 5. Seberapa sering kenyamanan tidur malam Anda terganggu oleh heartburn } \\
\text { dan atau regurgitasi yang Anda alami? }\end{array}$ & Poin & 0 & 1 & 2 & 3 & $\begin{array}{l}\text { Poin } \\
+\end{array}$ \\
\hline $\begin{array}{l}\text { 6. Seberapa sering Anda meminum obat tambahan untuk heartburn dan atau } \\
\text { regurgitasi yang Anda alami selain dari apa yang telah dianjurkan oleh } \\
\text { dokter? (seperti obat maag yang dijual bebas) }\end{array}$ & Poin & 0 & 1 & 2 & 3 & $\begin{array}{l}\text { Poin } \\
=\end{array}$ \\
\hline
\end{tabular}

After the validity of all questionnaire items was tested, the reliability was assessed to determine the consistency of the questionnaire if completed at different times. A Cronbach's a greater than the tabulated $\mathrm{r}$ value was accepted as reliable, and a value less than the tabulated r value was considered not reliable.

This study was reviewed and approved by the ethics committee of Faculty of Medicine University of Indonesia, by the letter number 38/PT02.FK/ ETIK/2009, dated 2 ${ }^{\text {nd }}$ February 2009.

\section{RESULTS}

Forty patients with a mucosal break or endoscopic oesophagitis identified in the endoscopic examination were enrolled. Twenty five (62.5\%) patients were men and the mean age $( \pm \mathrm{SD})$ was $41.3 \pm 12.2$ years (Table 1$)$.

Table 1. Respondents' characteristics

\begin{tabular}{lcc}
\hline & $\mathbf{n}$ & $\mathbf{\%}$ \\
\hline Sex & & \\
- Male & 25 & 62.5 \\
- Female & 15 & 37.5 \\
Age (Mean \pm SD) & $41.3 \pm 12.2$ & \\
Ethnicity & & \\
- Javanese & 22 & 55.0 \\
- Chinese & 10 & 25.0 \\
- Malay & 4 & 10.0 \\
- Dayak & 1 & 2.5 \\
- Papuan & 1 & 2.5 \\
- Moluccan & 1 & 2.5 \\
- Other & 1 & 2.5 \\
Body Mass Index & $23.5 \pm 4.2$ & \\
(Mean $\pm S D) ~ k g / m^{2}$ & & \\
& &
\end{tabular}

The GERD questionnaire comprised 6 questions, and the data are shown in Table 2. Most (67.5\%) of respondents had the symptom of a burning sensation behind the breastbone (heartburn) for 4-7 days. Sixty five percent of respondents reported having stomach contents (fluid) moving upwards to the throat or mouth (regurgitation) for 4-7 days. Seventy percent of respondents reported having pain in the centre of the upper abdomen for 4-7 days. Fifty seven point five percent of respondents reported having nausea for 4-7 days. Sixty two point five percent of respondents had difficulty sleeping because of the heartburn and/or regurgitation for 4-7 days. Sixty two point five percent of respondents took additional medication for heartburn and/or regurgitation for 4-7 days.

\section{Validity Test}

The corrected item total correlations for each question of the GERDQ were 0.61, 0.69, 0.50, 0.71, 0.67, and 0.47 (Table 3). All these values were greater than the tabulated $r$ value $(\mathrm{df}=38 ; \mathrm{r}=0.26)$, indicating that all questions had adequate validity (Table 3).

\section{Reliability Test}

In the test-retest analysis, Cronbach's a was 0.83 , which was greater than the tabulated $r$ value of 0.26 , demonstrating good reliability.

\section{DISCUSSION}

More men (62.5\%) than women were included in this study. Some studies have reported that GERD is more common in men, some have reported that GERD is more common in women, and yet others have reported an equal distribution of men and women. . $^{8,12-15}$

In this study, the mean age of the GERD patients was $41.3 \pm 12.2$ years, which is similar to the value of 46 years in a previous study. ${ }^{16}$ Another study found higher prevalence rates of nocturnal GERD, non-nocturnal GERD, and symptomatic GERD in patients aged 18-64 years than in those older than $65 .{ }^{17}$ 
Table 2. The GERDQ used to record the frequency of symptoms during the previous week

\begin{tabular}{|c|c|c|c|c|}
\hline \multirow{2}{*}{ Question } & \multicolumn{4}{|c|}{ Frequency of symptoms } \\
\hline & O days & 1 day & 2-3 days & 4-7 days \\
\hline $\begin{array}{l}\text { 1. How often did you have a burning feeling behind your breastbone } \\
\text { (regurgitation)? }\end{array}$ & $4(10.0 \%)$ & $4(10.0 \%)$ & $5(12.5 \%)$ & $27(67.5 \%)$ \\
\hline $\begin{array}{l}\text { 2. How often did you have stomach contents (liquid or food) moving } \\
\text { upwards to your throat or mouth (regurgitation)? }\end{array}$ & $6(15.0 \%)$ & $3(7.5 \%)$ & $5(12.5 \%)$ & $26(65.0 \%)$ \\
\hline 3. How often did you have a pain in the centre of the upper abdomen? & $4(10.0 \%)$ & $4(10.0 \%)$ & $4(10.0 \%)$ & $28(70.0 \%)$ \\
\hline 4. How often did you have nausea? & $10(25.0 \%)$ & $3(7.5 \%)$ & $4(10.0 \%)$ & $23(57.5 \%)$ \\
\hline $\begin{array}{l}\text { 5. How often did you have difficulty sleeping because of your heartburn } \\
\text { and/or regurgitation? }\end{array}$ & $6(15.0 \%)$ & $4(10.0 \%)$ & $5(12.5 \%)$ & $25(62.5 \%)$ \\
\hline $\begin{array}{l}\text { 6. How often did you take additional medication for heartburn and/or } \\
\text { regurgitation, other than what the physician told to you take? }\end{array}$ & $5(12.5 \%)$ & $1(2.5 \%)$ & $9(22.5 \%)$ & $25(62.5 \%)$ \\
\hline
\end{tabular}

Table 3. Validity statistics of the GERDQ

\begin{tabular}{cccccc}
\hline Question number & $\begin{array}{c}\text { Scale mean if item } \\
\text { was deleted }\end{array}$ & $\begin{array}{c}\text { Scale variance if item } \\
\text { was deleted }\end{array}$ & $\begin{array}{c}\text { Corrected item-Total } \\
\text { correlation }\end{array}$ & $\begin{array}{c}\text { Squared multiple } \\
\text { correlation }\end{array}$ & $\begin{array}{c}\text { Cronbach's alpha if } \\
\text { item was deleted }\end{array}$ \\
\hline 1 & 16.25 & 18.090 & 0.610 & 0.626 & 0.808 \\
2 & 16.35 & 16.797 & 0.692 & 0.823 & 0.790 \\
3 & 16.23 & 18.948 & 0.498 & 0.617 & 0.828 \\
4 & 16.63 & 15.522 & 0.710 & 0.800 & 0.785 \\
5 & 16.40 & 16.913 & 0.668 & 0.485 & 0.795 \\
6 & 16.28 & 19.179 & 0.474 & 0.291 & 0.832 \\
\hline
\end{tabular}

There are no good epidemiological data about the prevalence of GERD in any population in Indonesia, but data from Dr. Cipto Mangunkusumo General Hospital, University of Indonesia, Jakarta, show an increase in the prevalence of GERD from 6\% in 1997 to 26\% in 2002 in patients undergoing upper GI endoscopy. ${ }^{7}$ However, endoscopy is not widely available, and the typical reflux syndrome can be diagnosed on the basis of the characteristic symptoms without diagnostic testing. ${ }^{1,7}$

In this study, GERD was reported by more people of Javanese ethnicity (55\%). The relationship between ethnicity and GERD prevalence has not been studied by other researchers in Indonesia. Studies in Singapore and Malaysia found that GERD is more common in the Indian than in the Malay and Chinese populations; GERD is also more frequent in Caucasian than in Asian populations. ${ }^{4,18-19}$

The GERD patients in this study had a mean BMI of $23.50 \pm 4.2 \mathrm{~kg} / \mathrm{m}^{2}$; this value differs from other studies that found GERD is more common in obese people with a BMI $>30 \mathrm{~kg} / \mathrm{m}^{2}$ and central obesity. ${ }^{20,21}$

In our study, the GERDQ showed that 36 patients (90\%) had heartburn, suggesting that the GERDQ is an excellent tool for diagnosing heartburn as the main GERD symptom. A small percentage (10\%) of all patients did not understand or recognize their symptoms of GERD. Seventy per cent of our patients also had epigastric pain for 4-7 days as an additional symptom. This finding differs from that of Andrijani et al., who reported that severe epigastric pain, rather than heartburn, is the most common GERD symptom. ${ }^{11}$ The severity of heartburn symptoms indicates the severity of GERD and oesophageal mucosal breaks. Juwanto et al. found that heartburn is the most common symptom (56.26\%) of reflux-type dyspepsia, a typical GERD symptom. ${ }^{8}$ Lelosutan et al. found a $22.8 \%$ prevalence of oesophagitis in patients with dyspepsia, suggesting that dyspepsia symptoms such as epigastric pain overlap with typical GERD symptoms such as heartburn. ${ }^{9}$ Our study shows that GERD symptoms can occur as typical symptoms (e.g., heartburn) or as atypical symptoms (e.g., severe epigastric pain). Most patients in our study (65\%) mentioned regurgitation as an additional complaint, which agrees with the finding of Carlsson et al. that regurgitation is a typical additional complaint of GERD. ${ }^{22}$ Consistent with previous reports, ${ }^{22-24}$ most of our patients had nausea (57.5\%) and/or difficulty falling asleep at night (62.5\%) as additional complaints. Most of our patients (62.5\%) reported using medication to treat heartburn and/or regurgitation in addition to the medication given by their physician. This finding is consistent with the literature showing a $30 \%$ treatment failure rate of PPIs in eradicating GERD symptoms related to stress or emotions, or because of poor compliance. ${ }^{24,25}$ PPIs minimize gastric acid secretion and increase gastric acid $\mathrm{pH}$, and are thus 
the recommended class of medication worldwide for treating GERD symptoms. ${ }^{10}$

The calculated r value for every question in the Indonesianlanguage version of the GERDQ was higher than the tabulated $r$ value $(0.26)$. This shows that all questions in the Indonesian version are valid. This is consistent with other studies showing that all GERDQ questions originally written in English are valid when translated into the relevant language and used in other countries. ${ }^{1-3,7}$

The value for Cronbach's a in the Virginia study (0.83) was higher than the tabulated $r$ value $(0.26)$, indicating that all questions in the GERDQ are reliable. The reliability has been shown in other studies, such as the DIAMOND study, in which the English version of the GERDQ was found to be reliable for diagnosing GERD in other countries. ${ }^{1-3,7}$

In conclusion, this study achieved its primary objectives and showed that the GERDQ is valid and reliable for Indonesian-speaking GERD patients. This study's results were consistent with those of the DIAMOND study, which showed that the GERDQ can be used for the diagnosis of GERD based on symptoms.

\section{Acknowledgments}

We acknowledge PT AstraZeneca for supporting this study. We thank all gastroenterologists at Dr. Cipto Mangunkusumo Hospital, Dr. Hasan Sadikin Hospital, and Dr. Soetomo Hospital who recruited the patients. We also thanks to Hamzah Shatri, MD for statistics consulting, Aan Santi, BSc., for support and assistance in managing, analysing, and compiling the data, Indri Rizkiyani, BSc for support and assistance the study, and the nurses and other parties who strongly supported this study.

\section{REFERENCES}

1. Cao Y, Yan XY, Ma XQ, Wang R, Johansson S, Wallander MA et al. Validation of a survey methodology for gastroesophageal reflux disease in China. BMC Gastroenterology 2008; 8: 37.

2. Shaw MJ, Talley NJ, Beebe TJ, Rockwood T, Carlsson R, Adlis $\mathrm{S}$ et al. Initial validation of diagnostic questionnaire for gastroesophageal reflux disease. Am J Gastroenterol. 2001; 96: 52-7.

3. Armstrong D, Mönnikes H, Bardhan KD, Stanghellini V. The construction of a new evaluative GERD Questionnairemethods and state of the art. Digestion 2007; 75(suppl 1): 17-24.

4. Ho KY, Kang JY, Seow A. Prevalence of gastrointestinal symptoms in a multiracial Asian population, with particular reference to reflux-type symptoms. Am J Gastroenterol. 1998; 93: 1816-22.

5. Lim SL, GohWT, Lee JM, NgTP, Ho KY.Community medicine GI study group. Changing prevalence of gastroesophageal reflux with changing time: longitudinal study in an Asian population. J Gastroenterol Hepatol. 2005;20:995-1001.
6. Ho KY, Chan YH, Kang JY. Increasing trend of reflux esophagitis and decreasing trend of Helicobacter pylori infection in patients from a multiethnic Asian country. Am J Gastroenterol. 2005;100:1923-8.

7. Hastono SP. Data analysis. Faculty of Public Health, University of Indonesia. 2003.

8. Juwanto, Manan C, Rani AA. Diagnostic value of barium esophagogram and Bernstein test in patients with esophagitis. Indones J Gastroenterol Hepatol Dig Endosc. 2001; 2: 5-11.

9. Lelosutan SAR, Manan C, Nur BM. The role of gastric acidity and lower esophageal sphincter tone on esophagitis among dyspeptic patients. Indones J Gastroenterol Hepatol Dig Endosc. 2001; 2: 6-11.

10. Manan C. Current treatment of gastroesophageal-esophagitis reflux disease. Indones J Gastroenterol Hepatol Dig Endosc. 2001; 2: 31-4.

11. Andrijani PK, Manan C, Simadibrata M, Siregar P. Specific subjective symptoms for gastroesophageal reflux disease in ulcer like dyspepsia. Indones J Gastroenterol Hepatol Dig Endosc. 2004; 5: 7-14.

12. Tiing-Leong A, Fock KM, Ng TM, Eng-Kiong T, Chua TS, Tan J. A comparison of the clinical, demographic and psychiatric profiles among patients with erosive and nonerosive reflux disease in a multi-ethnic Asian country. World J Gastroenterol. 2005; 11: 3559-61.

13. Dent J, Vakil N, Jones R, Reimitz PE, Schöning U, Halling $\mathrm{K}$, Junghard $\mathrm{O}$, Lind $\mathrm{T}$. Validation of the reflux disease questionnaire for the diagnosis of gastroesophageal reflux disease in primary care. Gut 2007;56:A75.

14. Garcia-Compean D, Gonzales MV, Galindo G, Mar DA, Trevino JL, Martinez R et al. Prevalence of gastroesophageal reflux disease in patients with extraesophageal symptoms referred from otolaryngology, allergy, and cardiology practice: a prospective study. Dig Dis Sci. 2000; 18: 178-82.

15. Noraie M, Razjouyan H, Assady M, Malekzadeh R, NasseriMoghaddam S. Epidemiology of gastroesophageal reflux symptoms in Tehran, Iran: a population-based telephone survey. Arch Iran Med. 2007;10:289-94.

16. EslickGD, Talley NJ. Gastroesophageal reflux disease(GERD): risk factors, and impact on quality of life-a population-based study. J Clin Gastroenterol. 2009; 43: 111-7.

17. Ricci JA, Engelhart L, Sloan S, Leotta C, PCS A, Valley H et al. Age differences in the epidemiology and treatment of GERDrelated symptoms.(Cited 2010 May 23). Available from URL: http://www.ispor.org/research_source/free/PGS13.pdf.

18. Lim LG, Ho KY. Gastroesophageal reflux disease at the turn of millennium. World J Gastroenterol. 2003; 9: 2135-6.

19. Ho KY, Cheung TK, Wong BC. GERD in Asian countries: disorder of nature or nurture? Possible factors involved in the development of gastroesophageal reflux disease in Asia. J Gastroenterol Hepatol. 2006; 21: 1362-5.

20. Friedenberg FK, Xanthopoulos M, Foster GD, Richter JE. The association between gastroesophageal reflux disease and obesity. Am J Gastroenterol. 2008; 103: 2111-22.

21. Sijabat H. GERD in Obesity. Final thesis of Internal Medicine Residency Program Faculty of Medicine University of Indonesia 2009.

22. Carlsson R, Dent J, Bolling-Sternevald E, Johnson F, Junghard $\mathrm{O}$, Lauritsen Ket al. The usefulness of a structured questionnaire in the assessment of symptomatic gastroesophageal reflux disease. Scand J Gastroenterol. 1998; 33: 1023-9. 
23. Shaheen NJ, Madanick RD, Alattar M, Morgan DR, Davis $\mathrm{PH}$, Galanko JA et al. Gastroesophageal reflux disease as an etiology of sleep disturbance in subjects with insomnia and minimal reflux symptoms: a pilot study of prevalence and response to therapy. Dig Dis Sci. 2008; 53: 1493-9.

24. MedicineNet.com. Coping with GERD-survey result. 2005.(Cited 2010 May 24). Available from URL: http:// www.medicinenet.com/pdf/hr0505gerd.pdf.
25. Fass MSS, Fass R. Gastro-oesophageal reflux disease and psychological comorbidity: psychological comorbidity and GERD treatment.(Cited 2010 May 24). Available from URL: http://www.medscape.com/viewarticle/588970_7. 